
MANAGEMENT, AND ACCOUNTING

Fakultas Ekonomi Universitas Andi Djemma

J1. Puang H. Daud No 4 Kota Palopo

\title{
Ekonomi Wisata Pantai Ujung Suso Burau Kabupaten Luwu Timur
}

\author{
Penulis \\ Jibria Ratna Yasir ${ }^{1}$ \\ IAIN Palopo \\ Email:jibriaratna@gmail.com

\section{Wahida ${ }^{2}$} \\ Dosen Program Studi Ekonomi Pembangunan \\ Universitas Andi Djemma Palopo \\ Email: idha.tahir12@gmail.com
}

\author{
Info Artikel \\ p-ISSN : 2615-1871 \\ e-ISSN : 2615-5850 \\ Volume 3 Nomor 1, Maret 2020 \\ DOI: \\ http://dx.doi.org/10.35914/jemma.v3i1.344 \\ Article History: \\ Received, 13 Januari 2020 \\ Revised, 11 Februari 2020 \\ Accepted, 16 Maret 2020
}

\begin{abstract}
ABSTRAK
Wisata Bahari di Kecamatan Burau Kabupaten Luwu Timur sangat potensial untuk dikembangkan. Hal ini karena sebagian besar wilayahnya merupakan daerah pantai dan berbatasan langsung dengan Teluk Bone. Dua pantai yang terdapat di Kecamatan Burau dan menjadi kunjungan wisata adalah Pantai Lemo dan Pantai Ujung Suso. Pantai Ujung suso yang memiliki banyak potensi untuk dikelola, saat ini belum mendapatkan perhatian khusus dari Pemerintah Kabupaten Luwu Timur. Akibat dari kurangnya perhatian pemerintah dalam proses pengelolaan Pantai Ujung Suso berdampak buruk pada kondisi alamnya seperti parahnya erosi pantai yang menyebabkan jarak antara tepi laut dengan jalan semakin dekat, tumpukan sampah yang semakin banyak disekitar pantai dalam jangka waktu panjang dapat merusak ekosistem di pantai tersebut. Oleh karena itu saat ini dibutuhkan konsep pengelolaan wisata kawasan yang dapat memperbaiki kualitas sumberdaya alam Pantai Ujung Suso. Data yang dikumpulkan meliputi data pengunjung, potensi wisata yang terdiri dari potensi fisik, sosial budaya, serta ekonomi, dan metode pengelolaan Pantai Ujung Suso sebelumnya. Selanjutnya wawancara dan Indepth interview dilakukan untuk mengetahui bagaimana metode pengelolaan untuk pengembangan Pantai Ujung Suso dengan menggunakan SWOT. Hasil penelitian menunjukkan bahwa beberapa kekuatan yang merupakan potensi wisata Pantai Ujung Suso adalah social budaya masyarakat, ekosistem pantai, perekonomian, serta kemudahan akses. Selain kekuatan yang merupakan potensi Pantai Ujung Suso, ditemukan pula beberapa kelemahan seperti pengambilan terumbu karang liar oleh masyarakat, kebersihan lingkungan pantai yang semakin mengkhawatirkan akibat aktivitas pengunjung dan warung di sekitar pantai yang membuang sampah disekitar pantai, persepsi masyarakat terkait pengembanagan wisata adalah dengan mendatangkan wisatawan sebanyak-banyaknya. Partisipasi masyarakat dalam kegiatan wisata perlu dikembangkan dan didampingi. Selain itu wisata pantai Ujung Suso juga mempunayai peluang secara ekonomi dengan memberikan kesempatan kerja dan berusaha bagi masyarakat disekitar pantai.
\end{abstract}

Kata Kunci: Pantai, Ujung Suso, Kesesuaian wisata, Pengembangan wisata 


\section{PENDAHULUAN}

Kecamatan Burau Kabupaten Luwu Timur yang secara geografis terletak pada $2^{0} 25^{\prime}$ 50"- 20 40' 09" Lintang Selatan dan $120^{\circ} 33^{\prime}$ '08" - $121^{0} 46^{\prime} 35^{\prime}$ " Bujur Timur, dengan luas wilayah $256,23 \mathrm{~km}^{2}$, memiliki dua pantai yang sangat terkenal yaitu Pantai Lemo dan Pantai Ujung Suso. Wisata bahari di Kecamatan Burau menjadi pilihan wisata yang sangat potensial untuk dikembangkan karena sebagian besar wilayahnya yang merupakan daerah pantai dan berbatasan langsung dengan Teluk Bone.

Pantai Ujung Suso yang terletak di Desa Mabonta letaknya tidak jauh dari Pantai Lemo. Selain sebagai sentra budidaya rumput laut, Pantai Ujung Suso juga merupakan sumber penghidupan bagi masyarakat sekitar, karena banyak masyarakat yang berjualan makanan untuk para wisatawan serta cindera mata. Kegiatan wisata yang dapat dilakukan di Pantai Ujung Suso antara lain berenang, bermain air, dan wisata pancing serta penanaman karang.

Pantai Ujung Suso saat ini belum dikelola secara intensif. Kondisi ini terlihat dari semakin parahnya erosi pantai, sehingga banyak pohon-pohon yang tumbang karena tergerus ombak air laut. Hal ini menyebabkan jarak antara tepi laut dengan jalan yang awalnya puluhan meter sekarang tinggal beberapa meter, sehingga mengkhawatirkan penduduk yang bermukim disekitar pantai. Selain itu permasalahan lain yang penting untuk diperhatikan adalah masalah sampah. Tumpukan sampah yang semakin banyak di sekitar pantai sangat mengganggu dan dalam jangka waktu panjang dapat merusak ekosistem di Pantai tersebut.

Berdasarkan uraian diatas, maka yang menjadi permasalahan pokok dalam pengembangan wisata berkelanjutan di Pantai Ujung Suso adalah: Potensi Sumber daya fisik, ekonomi dan sosial budaya apa saja yang terdapat di Pantai Ujung Suso?

\section{METODE}

Saat ini terdapat konsep pengembangan kawasan yang memanfaatkan sumber daya alam dan lingkungan untuk kegiatan wisata dengan tetap menjaga kelestarian lingkungan, ekonomi, sosial dan budaya untuk kepentingan saat ini dan masa mendatang, yaitu konsep wisata berkelanjutan. Wisata berkelanjutan merupakan kegiatan wisata yang bertujuan untuk menjaga kelestarian sumber daya alam dan lingkungan, sehingga kegiatan wisata dapat dilakukan secara berkelanjutan. Dengan menggunakan prinsip-prinsip wisata berkelanjutan, diharapkan sumber daya alam, sosial dan budaya di Pantai Ujung Suso akan terjaga kelestariannya. Prinsip wisata yang berkelanjutan menurut (Dahuri et al., 1996) yaitu:

1. Penggunaan sumber daya secara berkelanjutan

2. Pengurangan konsumsi yang berlebihan dan limbah

3. Pemeliharaan terhadap keanekaragaman

4. Integrasi pariwisata ke dalam perencanaan

5. Dukungan terhadap perekonomian lokal

6. Pelibatan masyarakat lokal

7. Konsultasi terhadap stakeholder dan masyarakat

8. Pelatihan Staff

9. Pemasaran pariwisata yang bertanggung jawab

10. Penelitian 


\section{Metode Pengumpulan Data}

Metode pengumpulan data dilakukan melalui studi pustaka, wawancara dan pengamatan lapang, data yang dikumpulkan meliputi data kondisi umum (Tabel 1), data potensi wisata (Tabel 2), data pengunjung (Tabel 3)

Tabel 1. Kondisi Umum Pantai Ujung Suso

\begin{tabular}{|c|c|c|c|}
\hline No & Jenis Data & $\begin{array}{c}\text { Metode } \\
\text { Pengumpulan } \\
\text { Data }\end{array}$ & Informasi yang Dikumpulkan \\
\hline 1 & $\begin{array}{l}\text { Sejarah } \\
\text { Perkembangan } \\
\text { Kawasan }\end{array}$ & $\begin{array}{l}\text { Studi Pustaka dan } \\
\text { Wawancara }\end{array}$ & $\begin{array}{l}\text { - Luas Kawasan Pantai Ujung Suso } \\
\text { - Pengelolaan Kawasan Pantai Ujung } \\
\text { Suso } \\
\text { - Letak (administratif dan geografis) } \\
\text { - Luas Wilayah } \\
\text { - } \text { Batas Wilayah }\end{array}$ \\
\hline 2 & $\begin{array}{l}\text { Kondisi Lingkungan } \\
\text { Fisik }\end{array}$ & Studi Pustaka & $\begin{array}{l}\text { - Topografi } \\
\text { - Geologi dan Tanah (Jenis Tanah, } \\
\text { batuan dan tekstur } \\
\text { - Iklim } \\
\text { - Hidrologi } \\
\text { - Abrasi Pantai }\end{array}$ \\
\hline 3 & Masyarakat & $\begin{array}{l}\text { Wawancara dan } \\
\text { Studi Pustaka }\end{array}$ & $\begin{array}{l}\text { - Jumlah Penduduk } \\
\text { - Tingkat Pendidikan } \\
\text { - Mata Pencaharian } \\
\text { - Budaya dan Mitos yang berkembang } \\
\text { di masyarakat tentang kawasan } \\
\text { Pantai Ujung Suso, Kesenian, } \\
\text { kerajinan dan ritual adat }\end{array}$ \\
\hline
\end{tabular}

Tabel 2 Potensi Wisata Pantai Ujung Suso

\begin{tabular}{|c|c|c|c|}
\hline No & Jenis Data & $\begin{array}{c}\text { Metode } \\
\text { Pengumpulan } \\
\text { Data }\end{array}$ & Informasi Yang Dikumpulkan \\
\hline 1 & Fisik & $\begin{array}{l}\text { Pengamatan } \\
\text { Langsung } \\
\text { dilapang, studi } \\
\text { pustaka, dan } \\
\text { wawancara } \\
\text { dengan } \\
\text { masyarakat } \\
\text { sekitar dan } \\
\text { instansi terkait }\end{array}$ & $\begin{array}{l}\text { - Kedalaman Perairan } \\
\text { - Tipe Pantai } \\
\text { - Lebar Pantai } \\
\text { - Material dasar Perairan } \\
\text { - Kecepatan Arus } \\
\text { - Kemiringan Pantai } \\
\text { - Kecerahan Perairan } \\
\text { - Penutupan Lahan Pantai } \\
\text { - Ketersediaan air tawar } \\
\text { - Abrasi } \\
\text { - Tanah } \\
\text { - Atraksi alam dan hidupan luar }\end{array}$ \\
\hline 2 & $\begin{array}{ll}\text { Sosial } & \text { Budaya } \\
\text { Masyarakat } & \end{array}$ & $\begin{array}{l}\text { Pengamatan } \\
\text { Langsung } \\
\text { dilapang, studi }\end{array}$ & $\begin{array}{l}\text { - Struktur Sosial Masyarakat } \\
\text { - Ritual adat } \\
\text { - Kesenian masyarakat lokal }\end{array}$ \\
\hline
\end{tabular}




\begin{tabular}{|c|c|c|c|}
\hline & & $\begin{array}{l}\text { pustaka dan } \\
\text { wawancara } \\
\text { institusi } \\
\text { terkait/masyarakat }\end{array}$ & $\begin{array}{l}\text { - Kepercayaan (diantara masyarakat } \\
\text { pada pemerintah dan pada organisasi } \\
\text { non-pemerintah) } \\
\text { - Keterbukaan masyarakat lokal } \\
\text { - Hubungan masyarakat dengan } \\
\text { pendatang } \\
\text { - Harapan masyarakat terkait } \\
\text { pengembangan wisata berkelanjutan } \\
\text { Pantai Ujung Suso }\end{array}$ \\
\hline 3 & Ekonomi & Wawancara & $\begin{array}{l}\text { - Daya tarik utama kawasan Pantai } \\
\text { Ujung Suso } \\
\text { - Harapan pengunjung terkait } \\
\text { pengembangan wisata berkelanjutan }\end{array}$ \\
\hline
\end{tabular}

Tabel 3. Pengunjung Aktual dan Potensial di Pantai Ujung Suso

\begin{tabular}{|c|l|l|l|}
\hline No & \multicolumn{1}{|c|}{ Jenis Data } & \multicolumn{1}{|c|}{$\begin{array}{c}\text { Metode } \\
\text { Pengumpulan } \\
\text { Data }\end{array}$} & \multicolumn{1}{|c|}{ Informasi yang Dikumpulkan } \\
\hline 1 & Tujuan Kunjungan & $\begin{array}{l}\text { Wawancara dan } \\
\text { studi pustaka }\end{array}$ & $\begin{array}{l}\text { - Tujuan utama ke Pantai Ujung Suso } \\
\text { - Kegiatan wisata yang dilakukan di } \\
\text { Pantai Ujung Suso } \\
\text { - Lama Kunjungan } \\
\text { - Intensitas Kunjungan }\end{array}$ \\
\hline 2 & $\begin{array}{l}\text { Penilaian dan } \\
\text { Harapan Pengunjung }\end{array}$ & Wawancara & $\begin{array}{l}\text { Daya Tarik Utama kawasan Pantai } \\
\text { Ujung Suso } \\
\text { Harapan Pengunjung terkait } \\
\text { pengembangan wisata berkelanjutan }\end{array}$ \\
\hline
\end{tabular}

\section{HASIL DAN PEMBAHASAN}

\section{Pasir Hitam}

Pantai Ujung Suso mempunyai karateristik pantai yang berpasir hitam. Pasir hitam di Pantai Ujung Suso merupakan daya tarik tersendiri bagi wisatawan.

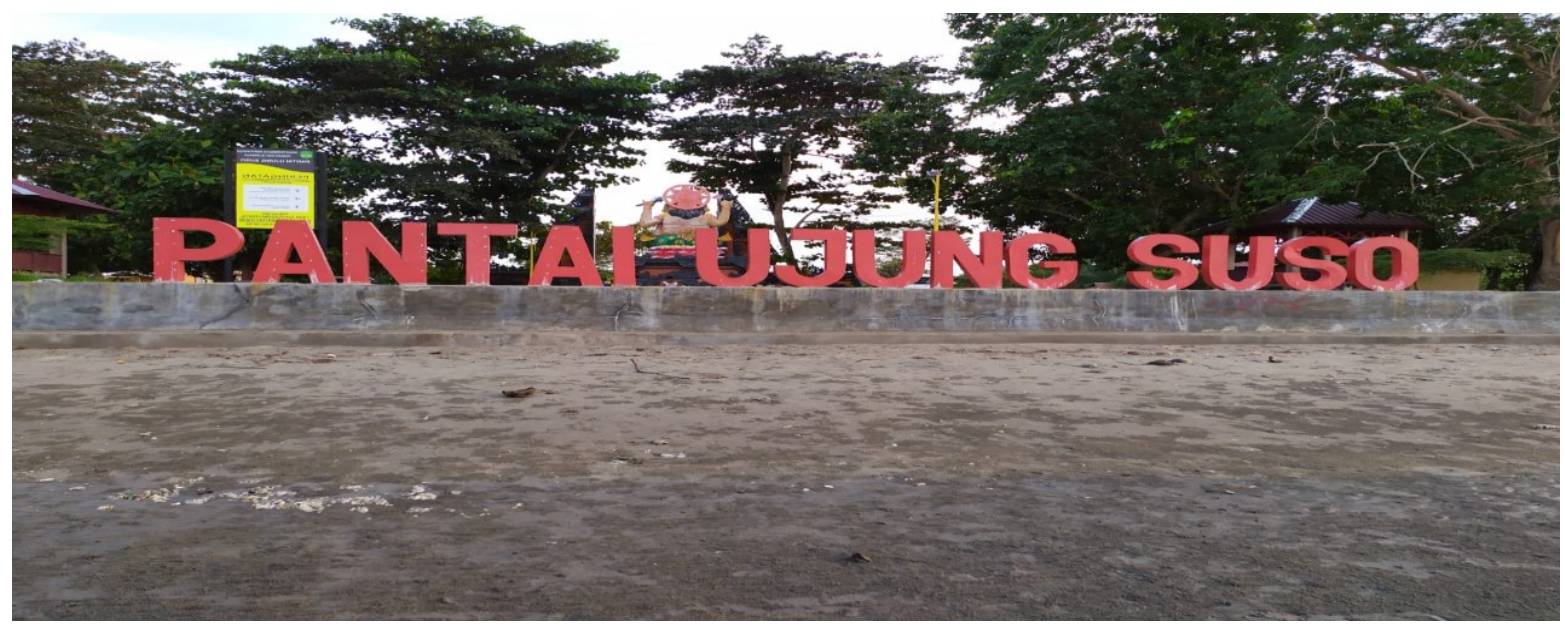

Gambar. 1 Pantai Ujung Suso yang Berpasir Hitam 
Beberapa pengunjung yang datang ke Pantai Ujung Suso hanya untuk membenamkan kaki mereka di pasir hitam. Berdasarkan wawancara dengan masyarakat sekitar, dengan membenamkan kaki di pasir hitam tersebut dapat menyembuhkan penyakit seperti reumatik dan asam urat.

\section{Pemandangan Lepas}

Pemandangan lepas di kawasan Pantai Ujung Suso memperlihatkan suatu bentang alam yang memiliki daya tarik wisata pantai dengan kondisi pantai berbatu dan ombak pantai yang tenang.

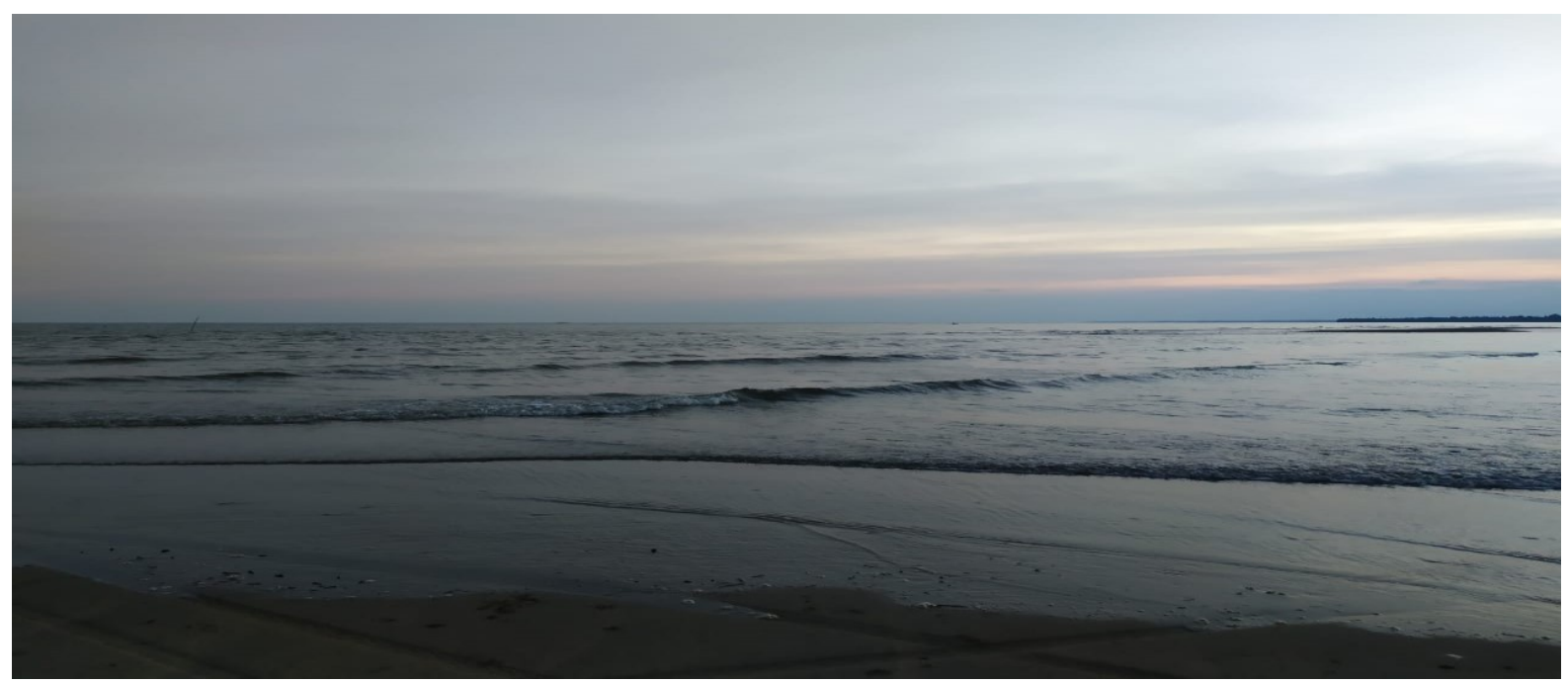

Gambar 2. Pantai Ujung Suso saat Senja

\section{Potensi Sosial Budaya}

Selain potensi fisik, kawasan Pantai Ujung Suso mempunyai potensi sosial budaya yang dapat menjadi daya tarik wisata. Potensi sosial budaya merupakan kegiatan dan hasil karya masyarakat Desa Mabonta yang dapat menjadi obyek wisata. Potensi sosial budaya masyarakat Desa Mabonta adalah sebagai berikut, kegiatan-kegiatan hari besar keagamaan hindu yang diperingati oleh sebagian besar masyarakat Bali yang berdomisili disekitar daerah Pantai Ujung Suso.

1. Masyarakat berikut:

Berdasarkan hasil pengamatan dan wawancara di lapangan, diperoleh hasil sebagai

a. Karateristik Masyarakat

Karateristik sosial masyarakat sekitar Pantai Ujung Suso adalah sebagai berikut seperti yang ditunjukkan pada tabel 4

Tabel. 4 Karateristik masyarakat sekitar Pantai Ujung Suso

\begin{tabular}{|c|l|l|l|l|}
\hline No & \multicolumn{1}{|c|}{ Parameter } & \multicolumn{1}{|c|}{ Kriteria } & \multicolumn{1}{|c|}{$\begin{array}{c}\text { Masyarakat } \\
(\mathbf{n = 3 0 )}\end{array}$} & Persentase (\%) \\
\hline 1 & Masyarakat & a. Laki-laki & 20 & 66.67 \\
& & b. Perempuan & 10 & 33.33 \\
\hline 2 & Umur & a. $15-25$ & 4 & 13.33 \\
& & b. $26-35$ & 10 & 33.33 \\
& & c. $36-45$ & 9 & 30 \\
& & d. $46-60$ & 7 & 23.33 \\
\hline
\end{tabular}




\begin{tabular}{|c|l|l|l|l|}
\hline 3 & Pendidikan & a. Perguruan Tinggi & 3 & 10 \\
& & b. SMA & 12 & 40 \\
& & c. SMP & 15 & 50 \\
& & 0 & 0 \\
\hline 4 & Pekerjaan & a. SD & 7 & 23.33 \\
& & b. Nelayan & 8 & 26.67 \\
& & c. Petani & 6 & 20 \\
& & d. Pedagang & 6.67 \\
\hline 5 & Bahasa yang dikuasai & e. Lainnya & 7 & 23.33 \\
& & a. Luwu & 12 & 40 \\
& & b. Bugis & 27 & 90 \\
& & c. Lainnya & 26 & 86.66 \\
\hline
\end{tabular}

Masyarakat sekitar Pantai Ujung Suso sebagian besar mempunyai umur antara 26-35. Kelompok umur tersebut merupakan kelompok usia produktif, yang dapat menjadi modal dalam pengembangan wisata karena pada usia tersebut terbuka peluang untuk melakukan berbagai kegiatan, sehingga lebih banyak masyarakat yang dapat berpartisipasi. Namun partisipasi tersebut harus dikendalikan untuk menjaga kelestarian alam dan lingkungan.

Tingkat pendidikan masyarakat di sekitar Pantai Ujung Suso masih rendah, hal ini dapat dilihat dari tingkat pendidikan sebagian besar adalah lulusan SMP (50\%). Pendidikan formal dalam pengembangan wisata berkelanjutan bukan hal yang utama, tetapi pengetahuan lokal yang mampu menjaga kelestarian alam merupakan kekuatan utama dalam pengelolaan wisata di Pantai Ujung Suso.

Sebagian besar masyarakat di sekitar pantai Ujung Suso mempunyai mata pencaharian petani terutama tanaman padi. Masayarakat sekitar Pantai Ujung Suso sebagian besar merupakan etnis Lombok, Bali, dan Luwu. Sehingga bahasa dan kebudayaannya merupakan campuran dari ketiga etnis tersebut. Masyarakat Desa Mabonta merupakan masyarakat yang patuh dan mengikuti apa yang menjadi ketentuan adat di kawasan tersebut. Selain itu, masyarakat sekitar Pantai Ujung Suso ini dapat bersosialisasi dengan baik, ini dibuktikan dengan awal kunjungan penelitian yang langsung mendapat sambutan sangat baik dan ramah.

Masyarakat sekitar juga sangat mendukung rencana pengembangan wisata Pantai Ujung Suso, dengan harapan bahwa pengelolaan Pantai Ujung Suso menjadi lebih baik sehingga memberikan lapangan pekerjaan bagi masyarakat dan tetap menjaga kelestarian sumber daya alam di kawasan Pantai Ujung Suso.

\section{b. Persepsi Masyarakat}

Persepsi masyarakat adalah pengetahuan dan pandangan mereka terhadap pengembangan wisata berkelanjutan di kawasan Pantai Ujung Suso. Persepsi masyarakat dapat diketahui dari pengetahuan dan pemahaman mereka terhadap kawasan Pantai Ujung Suso sebagai kawasan wisata pantai, pengetahuan terhadap tujuan wisatawan yang akan berkunjung ke kawasan Pantai Ujung Suso, keinginan terlibat langsung dalam pengembangan dan keinginan berpartisipasi lebih aktif dimasa mendatang di sajikan pada tabel 5 .

Tabel. 5 Pernyataan Pengunjung Aktual Dan Potensial di Pantai Ujung Suso

\begin{tabular}{|c|c|c|c|}
\hline No & Parameter & Jumlah $(\mathbf{n}=\mathbf{3 0})$ & Persentase (\%) \\
\hline 1 & $\begin{array}{l}\text { Pemahaman masyarakat tentang } \\
\text { kelestarian pantai Ujung Suso } \\
-\quad \begin{array}{l}\text { Memiliki pemahaman bahwa } \\
\text { pengembangan wisata dengan }\end{array}\end{array}$ & 7 & 23.33 \\
\hline
\end{tabular}




\begin{tabular}{|c|c|c|c|}
\hline & $\begin{array}{lr}\text { melestarikan sumberdaya alam } \\
\text { dan lingkungan } & \text { sangat } \\
\text { diperlukan } & \\
& \\
\text { Masyarakat } & \text { memiliki } \\
\text { pemahaman } & \text { bahwa } \\
\text { pengembangan } & \text { wisata } \\
\text { dilakukan } & \text { dengan } \\
\text { mendatangkan } & \text { banyak } \\
\text { wisatawan } & \\
\end{array}$ & 23 & 76.67 \\
\hline 2 & $\begin{array}{l}\text { Pengetahuan masyarakat tentang } \\
\text { status kawasan } \\
\text { - } \text { Masyarakat memiliki } \\
\text { pengetahuan bahwa status } \\
\text { kawasan tersebut adalah milik } \\
\text { pemerintah } \\
\text { - } \\
\text { Masyarakat memiliki } \\
\text { pengetahuan bahwa status } \\
\text { kawasan tersebut adalah } \\
\text { perorangan atau kelompok }\end{array}$ & 10 & $\begin{array}{l}33.33 \\
66.67\end{array}$ \\
\hline 3 & $\begin{array}{l}\text { Keinginan dan harapan masyarakat } \\
\text { untuk berperan akti dalam kegiatan } \\
\text { wisata } \\
- \text { Peningkatan penghasilan } \\
\text { - } \text { Berperan aktif dalam kegiatan } \\
\text { wisata adalah untuk } \\
\text { melestarikan sumberdaya alam } \\
\text { dan lingkungan }\end{array}$ & 30 & $\begin{array}{c}100 \\
0\end{array}$ \\
\hline
\end{tabular}

Persepsi masyarakat terhadap pengembangan wisata di kawasan Pantai Ujung Suso adalah dengan mendatangkan wisatawan sebanyak mungkin dan masyarakat juga beranggapan bahwa kawasan tersebut adalah milik masyarakat desa Mabonta, sehingga masyarakat berhak mengelola kawasan tersebut. Selain itu, masyarakat sekitar pantai Ujung Suso ingin berpartisipasi dalam pengembangan wisata di kawasan tersebut untuk menambah penghasilan mereka.

Hal ini menunjukkan bahwa tingkat kesadaran dan kepedulian masyarakat terhadap pelestarian sumber daya alam dan lingkungan di kawasan Pantai Ujung Suso masih kurang, sehingga untuk pemahaman mengenai pelestarian di dalam wisata berkelanjutan itu sendiri, harus ditingkatkan melalui penyuluhan dan kegiatan yang berhubungan dengan kelestarian sumber daya alam dan lingkungan.

c. Partisipasi Masyarakat

Partisipasi masyarakat terhadap pengembangan wisata berkelanjutan di kawasan Pantai Ujung Suso dapat dilihat dari tingkat pengetahuan masyarakat sekitar mengenai lokasi objek wisata yang potensial di kawasan tersebut dan peluang pekerjaan sampingan yang berhubungan dengan kegiatan wisata. Selain itu juga dapat dilihat dari partisipasi dan keinginan masyarakat untuk ikut terlibat langsung dalam pengelolaan kawasan dan pengembangan wisata berkelanjutan di kawasan Pantai Ujung Suso (Tabel 6) 
Tabel 6 Partisipasi masyarakat terhadap pengembangan wisata di kawasan Pantai Ujung Suso

\begin{tabular}{|c|l|l|c|c|}
\hline No & \multicolumn{1}{|c|}{ Parameter } & \multicolumn{1}{|c|}{ Kriteria } & $\begin{array}{c}\text { Jumlah } \\
(\mathbf{n = 3 0 )}\end{array}$ & $\begin{array}{c}\text { Persentase } \\
(\%)\end{array}$ \\
\hline 1 & $\begin{array}{l}\text { Pekerjaan yang berhubungan } \\
\text { dengan kawasan wisata } \\
\text { Pantai Ujung Suso }\end{array}$ & $\begin{array}{l}\text { a. Ya } \\
\text { b. Tidak }\end{array}$ & 14 & 46.67 \\
& Letak Lokasi Usaha & $\begin{array}{l}\text { a. Areal Pantai Ujung } \\
\text { Suso } \\
\text { b. Sekitar Pemukiman } \\
\text { Penduduk }\end{array}$ & 10 & 33.33 \\
\hline 3 & $\begin{array}{l}\text { Pengetahuan mendetail } \\
\text { tentang tempat-tempat } \\
\text { menarik untuk dikunjungi di } \\
\text { sekitar Pantai Ujung Suso }\end{array}$ & $\begin{array}{l}\text { a. Ya } \\
\text { b. Beberapa Saja } \\
\text { c. Tidak }\end{array}$ & 8 & 13.33 \\
\hline
\end{tabular}

Partisipasi masyarakat dalam kegiatan wisata di Pantai Ujung Suso meliputi penyedia perlengkapan wisata seperti pelampung dan perahu wisata, penyedia toilet, warung, pedagang asongan dan fotografer. Alasan masyarakat ikut berpartisipasi dalam kegiatan wisata adalah menambah penghasilan, karena mata pencaharian utama masyarakat sekitar adalah petani. Masyarakat yang mengetahui secara detail tentang kawasan tersebut merupakan masyarakat yang telah tinggal dalam waktu yang lama sehingga mengetahui secara mendetail lokasi yang menarik untuk dikunjungi, sedangkan masyarakat yang hanya mengetahui beberapa lokasi saja yang menarik untuk dikunjungi adalah masyarakat sekitar yang pernah berkunjung atau warga pendatang yang berasal dari wilayah di luar desa yang kini menetap di Desa Mabonta (Coria dan Calucura 2012).

\section{d. Saran dan Harapan Masyarakat}

Saran masyarakat sekitar Pantai Ujung Suso untuk pengembangan wisata adalah dapat membuka lapangan pekerjaan, adanya pengelolaan yang baik sehingga kebersihan, ketertiban dan keamanan di kawasan tersebut dapat terjaga. Selain itu masyarakat juga berharap adanya pencegahan terhadap abrasi dan terumbu karang yang semakin rusak. Pengetahuan yang dimiliki masyarakat sekitar dapat dijadikan sebagai suatu peluang dalam pengembangan wisata berkelanjutan di kawasan Pantai Ujung Suso dimasa yang akan datang. Jumlah wistawan yang semakin meningkat dan pengendalian terhadap aktivitas-aktivitas pengunjung di kawasan Pantai Ujung Suso supaya kelestarian alam dan lingkungan tetap terjaga, maka peran masyarakat sangat dibutuhkan sebagai pemandu wisata.

\section{Air Bersih}

Air bersih yang terdapat di kawasan Pantai Ujung Suso, yang dapat digunakan untuk umum sangat jernih pada kondisi normal (tidak ada hujan). Air bersih tersebut diusahakan secara swadaya oleh masyarakat untuk kepentingan wisata. Masyarakat mendapatkan air bersih tersebut dengan cara menggunakan sumur bor sedalam lebih dari 30 meter. Masyarakat juga membangun bilik-bilik kecil yang digunakan sebagai kamar mandi. Jarak sumber air tersebut dengan lokasi wisata sangat dekat, yaitu kurang dari 100 meter. 


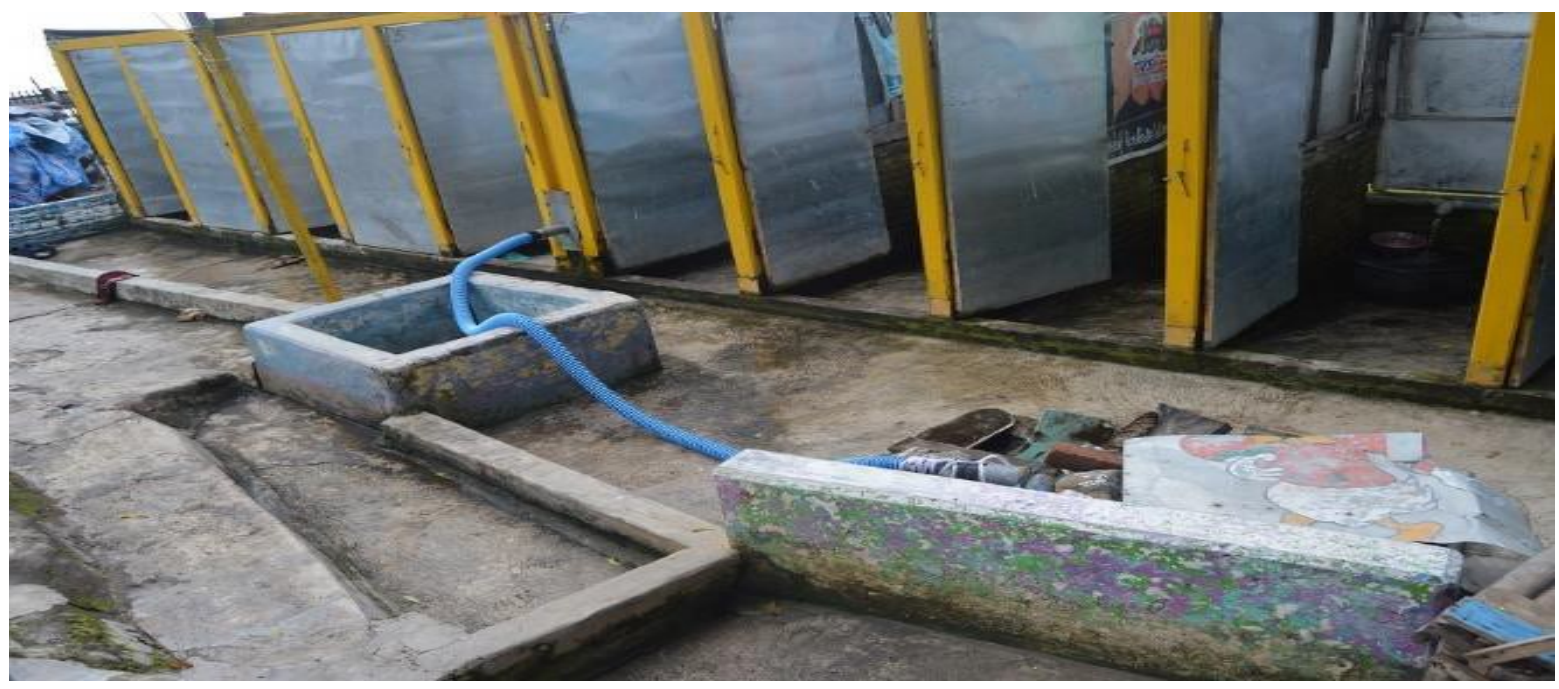

Gambar. 3 Bilik yang Digunakan Sebagai Kamar Mandi

Jalan darat antara pusat Kabupaten Luwu Timur dengan Pantai Ujung Suso seluruhnya telah diaspal. Lebar jalannya 3-5 meter dan terdapat dua jalur menuju Pantai Ujung Suso, Jalur timur dan jalur barat. Jalur timur berjarak $5 \mathrm{~km}$ dari jalan poros sedangkan jalur barat berjarak $8 \mathrm{~km}$ dari jalan poros. Sedangkan waktu tempuh dari pusat kota ke Pantai Ujung Suso sekitar 30 menit.

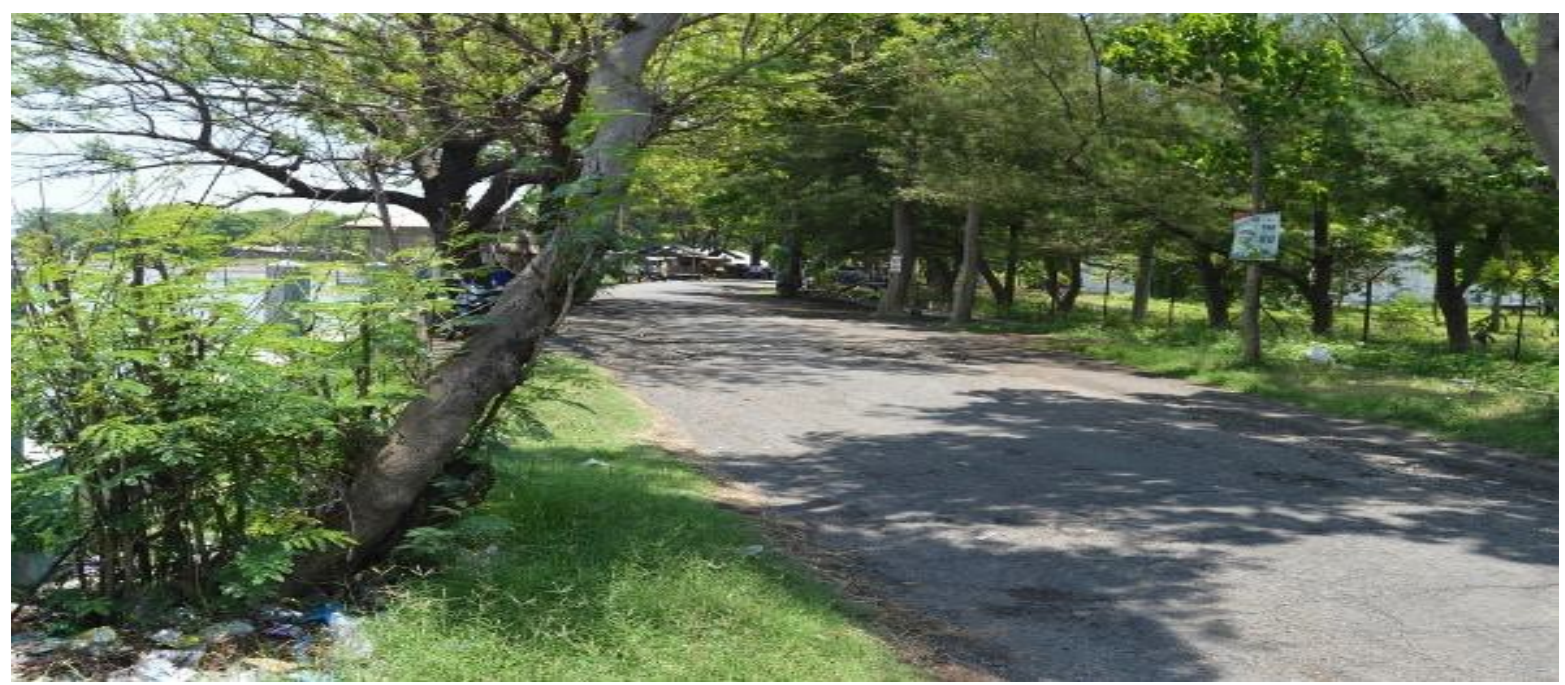

Gambar 4 Kondisi Jalan di Kawasan Pantai Ujung Suso

\section{Kesesuaian Wisata Pantai}

Tingkat kesesuaian wisata pantai dilakukan dengan mempertimbangkan 10 parameter. Sepuluh parameter tersebut adalah kedalaman perairan, tipe pantai, lebar pantai, material dasar perairan, kecepatan arus, kemiringan pantai, kecerahan perairan, penutupan lahan pantai, biota berbahaya dan ketersediaan air tawar.

Berdasarkan analisis kesesuaian wisata, kawasan pantai Ujung Suso terdapat 2 lokasi yang merupakan fokus pengembangan wisata dan dikategorikan cukup sesuai untuk wisata pantai kategori rekreasi. Lokasi pertama terletak disebelah barat daya dengan koordinat $113^{0} 59^{\prime} 10.01 \mathrm{BT}$ dan $7^{0} 39^{\prime} 30.05 \mathrm{LS}$ mempunyai luas area $3386 \mathrm{~m}^{2}$. Lokasi kedua terletak di sebelah timur laut dengan koordinat $113^{0} 59^{\prime} 48.53$ BT dan $7^{0} 38^{\prime} 11.95$ LS dan mempunyai dan mempunyai luas area $7149.29 \mathrm{~m}^{2}$. Kawasan sepanjang 226.87 meter ini merupakan area lahan terbuka, sebagian area pantainya berkarang, kecerahan $91.5 \%$ dan sangat dekat dengan sumber air tawar yaitu kurang dari 100 meter. 
Sedangkan lokasi kedua terletak di sebelah timur dengan luas area $7149.29 \mathrm{~m}^{2}$ sepanjang 526.82 meter. Area ini pantainya didominasi oleh pasir hitam merupakan lahan terbuka, kecerahan perairan yang mencapai 91.5\%, sangat dekat dengan sumber air tawar yaitu kurang dari 100 meter, tidak ada biota berbahaya di kawasan tersebut dan arus laut di Pantai Ujung Suso menurut Dinas Pariwisata dan Olahraga (2017) berkisar antara 0.05$0.1 \mathrm{~m} /$ detik.

\section{Kegiatan Pengunjung}

Berdasarkan hasil pengamatan di lapangan, responden berjumlah 45 orang yang terdiri dari pengungjung aktual 12 orang dan pengunjung potensial 33 orang. Karateristik pengungjung terhadap pengembangan wisata di alam kawasan pantai Ujung Suso di sajikan pada Tabel 6

a. Karateristik Pengunjung

Tabel 6 Karateristik pengunjung terhadap pengembangan wisata di kawasan Pantai Ujung Suso

\begin{tabular}{|c|c|c|c|c|c|c|}
\hline \multirow[b]{2}{*}{ No } & \multirow[b]{2}{*}{ Parameter } & \multirow[b]{2}{*}{ Kriteria } & \multicolumn{2}{|c|}{ Pengunjung } & \multirow[b]{2}{*}{ Total } & \multirow[b]{2}{*}{ Persentase } \\
\hline & & & $\begin{array}{l}\text { Aktual } \\
(n=12)\end{array}$ & $\begin{array}{c}\text { Potensial } \\
(\mathbf{n}=\mathbf{3 3})\end{array}$ & & \\
\hline 1 & Responden & $\begin{array}{l}\text { a. Laki-laki } \\
\text { b. Perempuan }\end{array}$ & $\begin{array}{l}7 \\
5\end{array}$ & $\begin{array}{l}23 \\
10\end{array}$ & $\begin{array}{l}30 \\
15\end{array}$ & $\begin{array}{l}66.67 \\
33.33 \\
\end{array}$ \\
\hline 2 & Umur & $\begin{array}{l}\text { a. } 15-25 \\
\text { b. } 26-35 \\
\text { c. } 36-45 \\
\text { d. } 46-60\end{array}$ & $\begin{array}{l}4 \\
4 \\
2 \\
2\end{array}$ & $\begin{array}{l}2 \\
15 \\
10 \\
6\end{array}$ & $\begin{array}{l}6 \\
19 \\
12 \\
8\end{array}$ & $\begin{array}{l}13.33 \\
42.22 \\
26.67 \\
17.78\end{array}$ \\
\hline 3 & Pendidikan & $\begin{array}{l}\text { a. Perguruan Tinggi } \\
\text { b. SMA } \\
\text { c. SMP } \\
\text { d. SD }\end{array}$ & $\begin{array}{l}1 \\
7 \\
4 \\
0\end{array}$ & $\begin{array}{l}8 \\
18 \\
6 \\
1\end{array}$ & $\begin{array}{l}9 \\
25 \\
10 \\
1\end{array}$ & $\begin{array}{l}20.00 \\
55.56 \\
22.22 \\
2.22\end{array}$ \\
\hline 4 & Pekerjaan & $\begin{array}{l}\text { a. Pelajar } \\
\text { b. Pegawai } \\
\text { c.Lainnya }\end{array}$ & $\begin{array}{l}8 \\
4 \\
0\end{array}$ & $\begin{array}{l}2 \\
25 \\
6 \\
\end{array}$ & $\begin{array}{l}10 \\
29 \\
6\end{array}$ & $\begin{array}{l}22.22 \\
64.44 \\
13.33 \\
\end{array}$ \\
\hline 5 & $\begin{array}{l}\text { Tempat } \\
\text { Tinggal }\end{array}$ & $\begin{array}{l}\text { a. Luwu Timur } \\
\text { b. Luar Luwu Timur }\end{array}$ & $\begin{array}{l}8 \\
4\end{array}$ & $\begin{array}{l}30 \\
3\end{array}$ & $\begin{array}{l}38 \\
7\end{array}$ & $\begin{array}{l}84.44 \\
15.56\end{array}$ \\
\hline 6 & $\begin{array}{l}\text { Jumlah } \\
\text { Kelompok }\end{array}$ & $\begin{array}{l}\text { a. Kelompok Keluarga } \\
\text { b. Klp Non Keluarga } \\
\text { c. Pasangan } \\
\text { d. Sendiri }\end{array}$ & $\begin{array}{l}4 \\
4 \\
4 \\
0\end{array}$ & $\begin{array}{l}15 \\
10 \\
6 \\
2\end{array}$ & $\begin{array}{l}19 \\
14 \\
10 \\
2\end{array}$ & $\begin{array}{l}42.22 \\
31.11 \\
22.22 \\
4.44\end{array}$ \\
\hline 7 & $\begin{array}{l}\text { Frekuensi } \\
\text { Berkunjung }\end{array}$ & $\begin{array}{l}\text { a. Lebih dari } 2 \text { Kali } \\
\text { b. } 1 \text { kali }\end{array}$ & $\begin{array}{l}12 \\
0\end{array}$ & $\begin{array}{l}33 \\
0\end{array}$ & $\begin{array}{l}45 \\
0\end{array}$ & $\begin{array}{l}100 \\
0\end{array}$ \\
\hline 8 & $\begin{array}{l}\text { Lama } \\
\text { Kunjungan }\end{array}$ & $\begin{array}{l}\text { a. } 1 \text { Hari } \\
\text { b. Lebih dari } 2 \text { Hari }\end{array}$ & $\begin{array}{l}12 \\
0\end{array}$ & $\begin{array}{l}33 \\
0\end{array}$ & $\begin{array}{l}45 \\
0\end{array}$ & $\begin{array}{l}100 \\
0\end{array}$ \\
\hline
\end{tabular}

Wisatawan yang berkunjung pada saat pengambilan data, sebagian besar mempunyai kisaran umur 26-35 tahun yang tergolong dewasa muda. Kisaran usia 26-35 tahun tergolong usia produktif untuk melakukan berbagai kegiatan, selain itu tingkat keingintahuan yang tinggi serta ditunjang oleh tingkat pendidikannya merupakan hal pendorong untuk mengetahui hal-hal yang baru (Fannel 1999).

Wisatawan yang berkunjung ke Pantai Ujung Suso sebagian besar merupakan pegawai, tetapi ada juga pelajar. Sedangkan tingkat pendidikan pengunjung juga beragam, 
tetapi tingkat pendidikan sebagian besar SMA. Dari hasil tersebut ternyata tingkat pendidikan tidak mempengaruhi keinginan dan pemahaman seseorang untuk melestarikan sumberdaya alam dan lingkungan Pantai Ujung Suso, hal tersebut dibuktikan bahwa semua pengunjung Pantai Ujung Suso sangat prihatin dengan kerusakan pantai karena erosi pantai dan semakin berserakannya sampah, bahkan beberapa kelompok pengunjung memungut sampah disekitarnya untuk dibuang ke tempat sampah terdekat.

Berdasarkan hasil pengamatan di lapang, wisatawan yang berkunjung umumnya bukan merupakan kunjungan pertama, tetapi telah beberapa kali berkunjung ke Pantai Ujung Suso. Selain itu wisatawan yang berkunjung ke Pantai Ujung Suso cenderung datang bersama keluarga dan dengan lama kunjungan 1 hari.

b. Motivasi Pengunjung

Tabel 7 Keinginan pengunjung terhadap kelestarian sumberdaya alam dan lingkungan di Pantai Ujung Suso

\begin{tabular}{|c|c|c|c|c|c|c|}
\hline \multirow[b]{2}{*}{ No } & \multirow[b]{2}{*}{ Parameter } & \multirow[b]{2}{*}{ Kriteria } & \multicolumn{2}{|c|}{ Pengunjung } & \multirow[b]{2}{*}{ Total } & \multirow[b]{2}{*}{ Persentase } \\
\hline & & & $\begin{array}{c}\text { Aktual } \\
(n=12)\end{array}$ & $\begin{array}{c}\text { Potensial } \\
(n=33)\end{array}$ & & \\
\hline 1 & $\begin{array}{l}\text { Tujuan } \\
\text { Berkunjung }\end{array}$ & $\begin{array}{l}\text { a. Menikmati } \\
\text { keindahan } \\
\text { pemandangan pantai } \\
\text { dan kenyamanan } \\
\text { kawasan } \\
\text { b. Mengisi waktu libur } \\
\text { dan keingintahuan } \\
\text { tempat (Pantai } \\
\text { Ujung Suso) } \\
\text { c. Melihat satwa dan } \\
\text { tumbuhan unik } \\
\text { dikawasan } \\
\text { d. Pendidikan } \\
\text { Lingkungan }\end{array}$ & 10 & $\begin{array}{l}4 \\
0\end{array}$ & 30 & $\begin{array}{c}10.91 \\
0\end{array}$ \\
\hline 2 & $\begin{array}{l}\text { Alasan } \\
\text { Berkunjung }\end{array}$ & $\begin{array}{l}\text { a. Pemandangan yang } \\
\text { indah dan udara } \\
\text { segar di kawasan } \\
\text { Pantai Ujung Suso } \\
\text { b. Suasana tenang dan } \\
\text { alami } \\
\text { c. Satwa yang menarik } \\
\text { untuk diamati } \\
\text { d. Tumbuhan yang } \\
\text { menarik untuk } \\
\text { diamati } \\
\text { e. Adanya nilai sejarah } \\
\text { pada kawasan } \\
\text { Pantai Ujung Suso } \\
\text { f. Adanya kehidupan } \\
\text { tradisional yang } \\
\text { menarik untuk } \\
\text { diamati }\end{array}$ & $\begin{array}{l}8 \\
0 \\
0\end{array}$ & $\begin{array}{l}15 \\
0 \\
0\end{array}$ & $\begin{array}{l}23 \\
0 \\
0\end{array}$ & $\begin{array}{c}41.82 \\
0 \\
0\end{array}$ \\
\hline
\end{tabular}




\begin{tabular}{|l|l|l|c|c|c|c|}
\hline 3 & $\begin{array}{l}\text { Sumber } \\
\text { Informasi }\end{array}$ & $\begin{array}{l}\text { a. Media cetak } \\
\text { (Majalah Koran) } \\
\text { b. Media elektronik } \\
\text { (Radio, T, Internet) }\end{array}$ & 0 & 0 & 0 & 0 \\
$\begin{array}{l}\text { c. Cerita dari Orang } \\
\text { (Saudara, Teman, } \\
\text { dll) } \\
\text { d. Lainnya }\end{array}$ & 12 & 33 & 45 & 100 \\
\hline
\end{tabular}

Berdasarkan hasil pengamatan lapang, motivasi pengunjung yang berwisata ke pantai Ujung Suso adalah untuk menikmati keindahan pemandangan pantai dan kenyamanan kawasan. Pemandangan yang indah dan udara segar di kawasan Pantai Ujung Suso merupakan alasan yang terbesar yang digunakan wisatawan untuk mengunjungi pantai Ujung Suso. Hal ini berarti, sumber daya alam di kawasan pantai Ujung Suso merupakan daya tarik utama bagi pengunjung, sehingga kelestarian sumber daya alam di kawasan tersebut harus tetap terjaga. Selain itu, semua pengunjung mendapatkan informasi tentang Pantai Ujung Suso berasal dari cerita dari teman, saudara, dll. Hal ini cerita mengenai kawasan pantai Ujung Suso dari orang ke orang merupakan sarana promosi yang efektif, sehingga kawasan pantai Ujung Suso telah dikenal oleh masyarakat Kabupaten Luwu Timur dan sekitarnya.

\section{c. Persepsi Pengunjung}

Persepsi pengunjung disini merupakan pengetahuan pengunjung terhadap pengembangan wisata di Pantai Ujung Suso. Pengembangan wisata di Pantai Ujung Suso ini bertujuan untuk melestarikan sumber daya fisik, ekonomi, dan sosial budaya di kawasan Pantai Ujung Suso. Persepsi responden terhadap pengembangan wisata dapat dilihat pada tabel 8

Tabel 8 Persepsi pengunjung terhadap pengembangan wisata di Pantai Ujung Suso

\begin{tabular}{|c|c|c|c|c|c|}
\hline \multirow[b]{2}{*}{ No } & \multirow[b]{2}{*}{ Parameter } & \multicolumn{2}{|c|}{ Wisatawan } & \multirow[b]{2}{*}{ Total } & \multirow[b]{2}{*}{ Persentase } \\
\hline & & $\begin{array}{l}\text { Aktual } \\
(n=12)\end{array}$ & $\begin{array}{c}\text { Potensial } \\
(n=33)\end{array}$ & & \\
\hline 1 & $\begin{array}{l}\text { Istilah Ekowisata } \\
\text { - Pengunjung mengetahui } \\
\text { istilah ekowisata } \\
\text { - } \text { Pengunjung tidak } \\
\text { mengetahui istilah } \\
\text { ekowisata }\end{array}$ & $\begin{array}{c}0 \\
12\end{array}$ & $\begin{array}{c}27 \\
6\end{array}$ & $\begin{array}{l}27 \\
18\end{array}$ & $\begin{array}{l}60 \\
40\end{array}$ \\
\hline 2 & $\begin{array}{l}\text { Pengetahuan tentang } \\
\text { pelestarian sumber daya } \\
\text { alam dan lingkungan } \\
\text { - Pengunjung mengetahui } \\
\text { bahwa pengembangan } \\
\text { wisata adalah dengan } \\
\text { pelestarian sumber daya } \\
\text { alam } \\
\text { - Pengunjung mengetahui } \\
\text { bahwa pengembangan } \\
\text { wisata adalah dengan } \\
\text { penambahan fasilitas- } \\
\text { fasilitas wisata }\end{array}$ & 12 & 32 & 44 & 97.78 \\
\hline
\end{tabular}


Persepsi pengunjung aktual terhadap pengembangan wisata di Pantai Ujung Suso adalah dengan penambahan fasilitas, seperti penginapan, teman, arena bermain, dan lahan parkir. Sedangkan persepsi pengunjung potensial terhadap pengembangan wisatawan pantai Ujung Suso adalah dengan menjadikan pantai Ujung Suso sebagai kawasan tertutup. Artinya di kawasan pantai Ujung Suso itu bebas kendaraan bermotor, sehingga jalan yang ada sekarang dialihkan. Selain itu penanaman mangrove dilokasi-lokasi yang sesuai dengan habitat mangrove harus dilakukan, untuk menanggulangi abrasi pantai selain itu dapat juga dijadikan objek dan daya tarik wisata.

Aktivitas pengunjung juga dapat menyebabkan menurunnya kualitas lingkungan di kawasan Pantai Ujung Suso. Sampah yang ada di kawasan Pantai Ujung suso semakin banyak dan menumpuk hal ini disebabkan oleh tingkat kepedulian pengunjung akan kebersihan lingkungan masih rendah, sehingga membuang sampah di kawasan tersebut menjadi alasan bagi pengunjung untuk membuang disembarang tempat. Selain itu aktivitas pengunjung, warung-warung di Pantai Ujung Suso juga menumpuk sampahnya di sekitar pantai, sehingga tumpukan sampah semakin banyak. Saat ini, masyarakat setempat bersama aparat Desa Mabonta setiap minggu secara swadaya membersihkan sampah-sampah tersebut dari pantai.

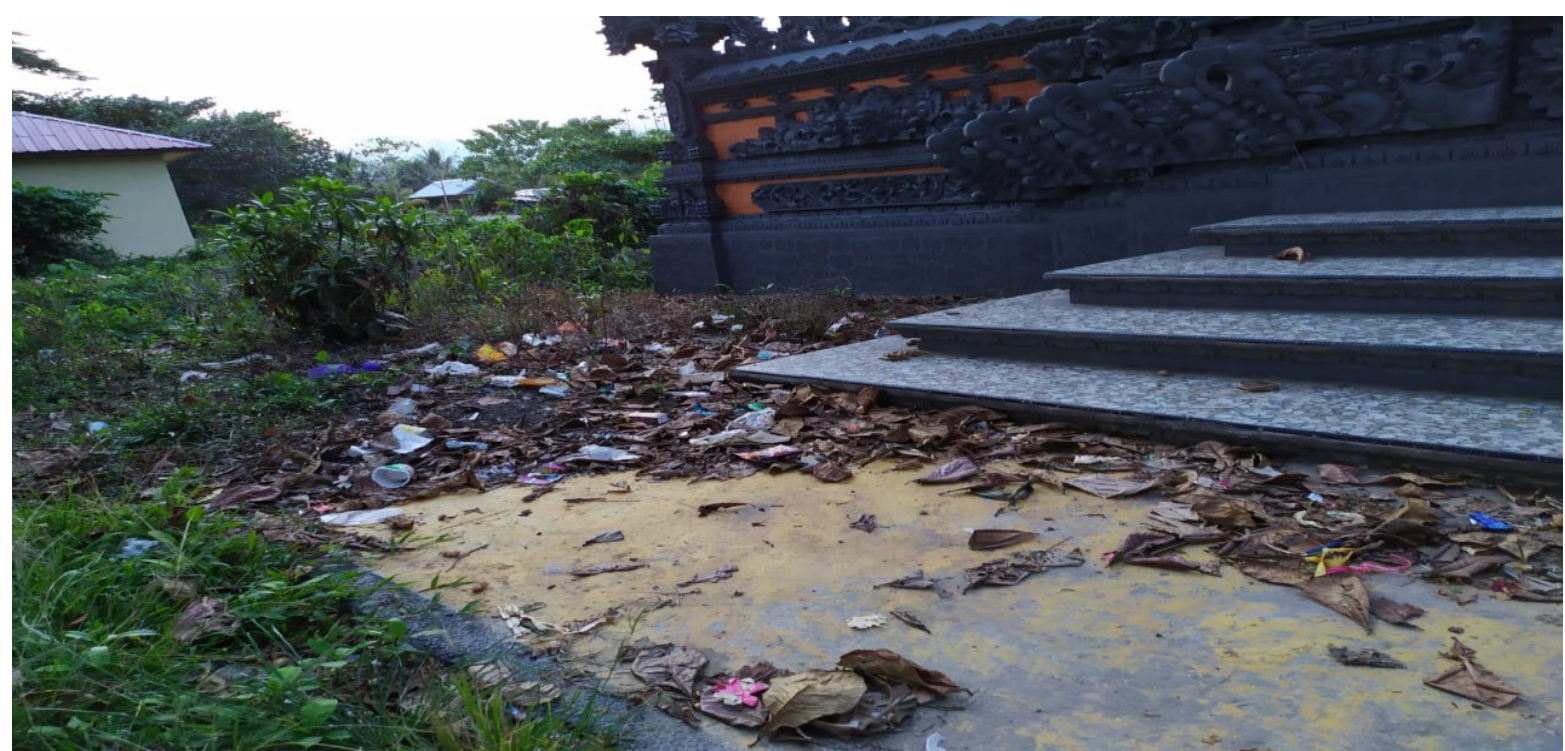

Gambar 5. Tumpukan Sampah Di Pantai Ujung Suso

\section{d. Saran dan Harapan Pengunjung}

Saran yang disampaikan pengunjung untuk pengembangan wisata di kawasan Pantai Ujung Suso adalah kebersihan pantai dan sekitarnya yang harus ditingkatkan, pencegahan abrasi pantai yang semakin meluas dan pengelolaan kawasan wisata Pantai Ujung suso dengan melibatkan berbagai pihak. Pengunjung juga menginginkan adanya informasi yang lengkap mengenai potensi-potensi wisata yang terdapat di Pantai Ujung Suso. Selain itu, pengunjung berharap dengan adanya pengembangan wisata berkelanjutan di kawasan Pantai Ujung Suso dapat meningkatkan peran serta masyarakat sekitar dan membuka lapangan pekerjaan bagi masyarakat sekitar. 


\section{DAFTAR PUSTAKA}

Kemenparekraf Kementrian Pariwisata dan Ekonomi Kreatif. 2012. Rencana Strategis 20122014. Jakarta (ID): Dirjen. Pengembangan Destinasi Pariwisata.

Dahuri, R, J. Rais, S.P. Ginting dan M.J. Sitepu. 1996. Pengelolaan Sumber Daya Wilayah Pesisir dan Lautan Secara Terpadu. Jakarta.xxxiv+305 hlm.

Bengen D.G. 2001. Ekosistem dan Suberdaya Pesisir dan Laut serta Pengelolaan Secara Terpadu dan Berkelanjutan [Makalah]. Disampaikan pada Prosiding Pelatihan Pengelolaan Wilayah Pesisir Terpadu. Bogor, 29 Oktober-3 November 2001. $159 \mathrm{hlm}$

Yulianda F. 2007. Ekowisata bahari sebagai alternatif pemanfaatan sumberdaya pesisir berbasis konservasi. Seminar sains 21 Februari 2007 pada Departemen Manajemen Sumberdaya Perairan. Bogor (ID): Fakultas Perikanan dan Ilmu Kelautan. Institut Pertanian Bogor.

Reihanian A, Mahmood NZB, Kahrom E, Hin TW. 2012. Sustainable tourism development strategy by SWOT analysis: Boujagh National Park, Iran. Tourism Management Perspectives 4:223-228. doi: 10.1016/j.tmp.2012.08.005

Coria J, Calucura E. 2012 Ecotourirsm and the Development of Indigenous Communities: The good, the Bad, and the Ugly. Ecol. Econom. 73:47-55.

Fennell DA. 1999. Ecotourism. New York (US): Routlege

Fennel DA. 2002. Ecotourism Programme Planing Trowbridge. (UK): CABI 